\title{
РЕВИЗСКИЕ СКАЗКИ
}

\section{КАК ИСТОЧНИК ИЗУЧЕНИЯ ИСТОРИЧЕСКОЙ ДЕМОГРАФИИ В ИСТОРИОГРАФИИ 1950-1960-Х ГОДОВ*}

\author{
Г. Н. УЛЬЯНОВА, И. А. ТРОИЦКАЯ
}

\begin{abstract}
В статье рассмотрен важный период в изучении ревизских сказок - 1950-1960-е годы. Он начался с публикации в 1952 г. статьи Е. П. Подъяпольской «Ревизские сказки как исторический источник» в сборнике к 70-летию академика Б. Д. Грекова, выпущенном Институтом истории АН СССР. Интерес к ревизским сказкам как массовому источнику возобновился после 35 -летнего периода забвения, когда в силу изменений в политической жизни страны стал наблюдаться отход от прежней, господствовавшей в предыдущее 20летие жесткой идеологической матрицы. При рассмотрении социально-экономической истории страны в XVIII и XIX вв. историки вновь возвратились к академической постановке вопросов. Число работ, использовавших ревизские сказки, было невелико, но их отличала глубина и тщательность анализа. Был введен в научный оборот значительный объем документов, особенно из фондов Российского государственного архива древних актов и Российского государственного исторического архива. В статье проанализированы работы, в которых изучалось положение различных категорий крестьянства в разных губерниях, в том числе население горнозаводских округов. Период 1960-х гг. также стал важным этапом в изучении на основе анализа ревизских сказок социальной структуры городов и их ремесленной специализации. Особое внимание в статье уделено роли трех исследователей в истории исторической демографии - В. К. Яцунского в создании научной школы в этой области, В. М. Кабузана во введении в оборот ревизских сказок для изучения различных аспектов демографической истории Российской империи и Н. А. Горской в детальном анализе обширного историографического поля.
\end{abstract}

Изучение ревизских сказок имеет давнюю традицию в российской историографии. Поэтому в начале нашего историографического обзора следует пояснить, что поскольку историки, работающие с массовыми источниками, включая ре-

${ }^{*}$ Исследование выполнено при финансовой поддержке РГНФ. Проект № 15-01-00362 «Демографическая история московского купечества по ревизским сказкам III-X ревизий (1762-1858 гг.): брак и семья, рождаемость и смертность, социальная и территориальная мобильность». 
визские сказки, прежде не раз публиковали историографические тексты, в которых иногда затрагивался и период 1950-1960-х гг., то мы остановимся на трех основных вопросах, избранных для рассуждений. Во-первых, на результатах наиболее содержательных работ, где в качестве источника применялись ревизские сказки. Во-вторых, на работах, которые использовали ревизские сказки для изучения податных сословий кроме крестьянства (купцов и мещан в городах). В-третьих, на наиболее содержательных достижениях исследователей, занимавшихся изучением этого вопроса ${ }^{1}$.

В каждую эпоху фокус интереса историков в отношении проблематики исследований и информационного потенциала источников меняется, поэтому далее мы рассмотрим историографию 1950-1960-х гг. с точки зрения современных исследовательских интересов. Важным, на наш взгляд, является обращение к биографиям исследователей в тех случаях, когда это возможно.

Говоря об использовании ревизских сказок в качестве источника в историографии 1950-х - начала 1960-х гг., следует сказать, что это был период возобновления интереса к сказкам после 35 -летнего периода забвения. Число работ, использовавших ревизские сказки, было невелико, но их отличала глубина и тщательность анализа.

Историографическое осмысление феномена изучения ревизских сказок впервые было предпринято в начале 1950-х гг., когда в сборнике Института истории АН СССР к 70-летию Б. Д. Грекова была опубликована статья Е. П. Подъяпольской «Ревизские сказки как исторический источник» ${ }^{2}$. К моменту публикации статьи Елена Петровна Подъяпольская (1895-1986) ${ }^{3}$ уже давно не занималась ревизскими сказками. Публикацией статьи она лишь отдала дань увлечению своей молодости, когда в 1920-е гг. в Саратове входила в кружок известного историка Саратовского края А. А. Гераклитова (1867-1933). Этот кружок «по изучению ревизских сказок в Нижне-Волжском областном научном обществе краеведения в Саратове» действовал в 1926-1927 гг., и в статье упомянуты его члены - Е. П. Подъяпольская, Е. Н. Кушева, П. Д. Степанов ${ }^{4}$. Участники кружка ставили целью изучение подлинных ревизских сказок, а не их итоговых данных. Причем они стремились извлекать из сказок не только

\footnotetext{
${ }^{1}$ В статье будут рассмотрены труды историков, главным образом использовавших архивные материалы. Мы оставим в стороне работы экономистов, например книгу А. Г. Рашина «Население России за 100 лет (1811-1913), вышедшую в 1956 г. и опиравшуюся на опубликованные материалы VI, VIII и XIX ревизий.

${ }^{2}$ Подбяпольская Е. П. Ревизские сказки как исторический источник // Академику Б. Д. Грекову ко дню семидесятилетия. М., 1952. С. 311-321.

${ }^{3}$ Елена Петровна Подъяпольская (1895-1986), согласно сведениям из личного дела, работала в Институте истории РАН с 1 июня 1944 г. младшим научным сотрудником. В 1924 г. Е. П. Подъяпольская окончила Саратовский университет. Под руководством А. А. Гераклитова и П. Г. Любомирова ею была написана дипломная работа «К вопросу о поместном землевладении и колонизации в районе Аткарского уезда», основанная на анализе ревизских сказок III и IV ревизий. Это была первая работа Е. П. Подъяпольской, опубликованная в 1927 г. в трудах Нижне-Волжского краеведческого института, а затем и отдельной книжечкой в 71 страницу (см.: Автобиография Е. П. Подъяпольской (Архив ИРИ РАН. Ф.10. ОП. 5. Ед. хр. 22. Л. 90-95; Ед. хр. 22. Л. 5-7).

${ }^{4}$ См.: Подъяпольская. Указ. соч. С. 315.
} 
Г. Н. Ульянова, И. А. Троицкая. Ревизские сказки как источник изучения исторической демографии...

историко-демографические показатели, но и нарративы, отражающие особенности повседневной жизни крестьян (например, влияние восстания Пугачева). Подъяпольская в статье приводит формуляр бланка, составленного ею в 1920-е гг., в котором, как она пишет, «мы стремились охватить всё многообразие данных сказки четвертой ревизии сельских местностей» ${ }^{5}$. Саратовский кружок работал с архивными сказками I-IV ревизий, и затем, в 1926-1929 гг., по итогам штудий был опубликован ряд работ.

Впоследствии Е. П. Подъяпольская и Е. Н. Кушева переселились в Москву (соответственно в 1930 и в 1929 гг.), защитили диссертации (Подъяпольская кандидатскую в 1963 г. в Институте истории АН СССР, Кушева - кандидатскую в 1938 г. в МИФЛИ, докторскую - в 1965 г. в Институте истории АН СССР)6. Кушева работала в Институте истории АН СССР с момента основания в 1936 г., Подъяпольская в 1936-1937 гг., и потом с 1944 г.

Подъяпольская отметила два важных момента в применении материалов ревизий населения в качестве исторического источника. Во-первых, «специалисты, писавшие о ревизиях, привлекали в качестве источника для изучения ревизий итоговые данные, составлявшиеся по окончании ревизий и содержащие официальные итоги их: “генеральные ведомости", “перечневые ведомости", государственные окладные книги, официальные таблицы. К основному источнику - ревизским сказкам - исследователи не обращались» ${ }^{7}$

Второй момент: «Попытки привлечь ревизские сказки как исторический источник связаны с изучением местной краевой истории» ${ }^{8}$ В качестве примера она приводит работу А. А. Голомбиевского по материалам Саратовской губ., опубликованную в 1890 г.

Небольшая по объему статья Подъяпольской насыщена содержательно. В ней содержится глубокий анализ предшествующей историографии и законодательства. На основе Полного собрания законов Подъяпольская выявила законоположения 1718-1761 гг. относительно проведения ревизий и поставила вопрос об ограничениях, выяснив, какие категории населения ревизиям не подвергались (а именно: духовенство, дворяне, отставные солдаты и драгуны, некоторые иноверцы - астраханские и уфимские татары и башкиры, ясачное население Сибири, лопари Архангельской губ.).

После публикации статьи Е. П. Подъяпольской в 1950-е гг. появился ряд статей, в которых изучалось положение отдельных категорий крестьянства в разных губерниях. Главным образом эти вопросы привлекали историков XVIII в., то есть вводились в научный оборот архивные материалы первых ревизий.

Положение дворцовых крестьян по ревизским сказкам изучали С. И. Волков и позже Е. И. Индова. В статье Волкова «Подмосковные дворцовые крестьяне в середине XVIII в.» ${ }^{9}$ были проанализированы данные I-III ревизий о численно-

\footnotetext{
${ }^{5}$ Подбяпольская. Указ. соч. С. 321.

${ }^{6}$ Архив ИРИ РАН. Ф. 10. Оп. 5. Ед. хр. 14. Л. 90-95; Ед. хр. 22. Л. 3, 6.

${ }^{7}$ Подъяпольская. Указ. соч. С. 313.

${ }^{8}$ Там же.

${ }^{9}$ Волков С. И. Подмосковные дворцовые крестьяне в середине XVIII в. // Исторические записки. М., 1955. Т. 53. С. 219-257.
} 
сти дворцовых крестьян и установлено, что доля их в крестьянском населении составляла соответственно 7,4\% (1724), 7,2\% (1743-1746) и 6,7\% (1762-1766), а количество колебалось в пределах 1-3 млн чел. Волковым также даны сведения о распределении дворцовых крестьян по губерниям в I ревизию - лидировали Нижегородская, Московская и Архангелогородская губернии, где доля дворцовых крестьян составляла от $25 \%$ до $15 \%$. Статья содержит и другие ценные таблицы, в том числе о демографических параметрах подмосковных дворцовых сел Измайлово, Люберцы, Котельники, Батюнино и др.

Индова в книге «Дворцовое хозяйство в России. Первая половина XVIII века» в главе «Территория и население» использовала данные I-III ревизий для определения динамики численности и расселения категории дворцовых крестьян ${ }^{10}$. Особое внимание было уделено конюшенным крестьянам (их было 34198 душ мужского пола по II ревизии), бобылям, сокольим помытчикам.

В статье работавшего в Курске (после 1951 г. в Москве) историка Ф. И. Лаппо (1904-1986) «Ревизские сказки как источник по истории русского крестьянства (по материалам III ревизии)» ${ }^{11}$ были рассмотрены историческая демография Белгородской провинции на основе данных проводимой местными властями III ревизии 1762 г. Источники были обнаружены автором в государственном архиве Курской области и тщательно обработаны. Лаппо описал технологию проведения ревизии, последующее сравнение полученных сказок со сказками II ревизии. Полученные данные позволили рассмотреть демографические и социально-экономические аспекты жизни податного населения. В результате в статье были представлены данные о миграции (переселение крестьян помещиками, купля-продажа, закрепощение или освобождение), убыли населения (включая, наряду с естественной убылью, бегство и рекрутские наборы), причинах смертности, о сокращении числа однодворцев. Лаппо отметил, что ряд сказок содержит сведения о количестве земли в домохозяйстве, характере ее приобретения. Имеются в приложении к статье и рекомендации по систематизации материала из ревизских сказок. Говоря о месте статьи Лаппо в историографическом процессе, следует сказать, что она явилась одной из первых работ, где была проведена тщательная и сплошная обработка ревизских сказок по обширному району (несколько уездов).

Ревизские сказки для выявления демографических показателей населения горнозаводских округов использовала П. А. Вагина в опубликованной в 1954 г. статье «Формирование рабочих кадров на заводах Южного Урала в 50-60-х годах XVIII в.» ${ }^{12}$. Автор использовала материалы из РГАДА, в том числе ревизские сказки Оренбургской губ. II и III ревизий из фонда Берг-коллегии, а также из областного архива в Свердловске (ныне Екатеринбург). Это позволило сделать вывод, что среди заводов Южного Урала преобладали предприятия, использо-

${ }^{10}$ См.: Индова Е. И. Дворцовое хозяйство в России. Первая половина XVIII века. М., 1964. C. $189-210$.

${ }^{11}$ Лаппо Ф. И. Ревизские сказки как источник по истории русского крестьянства (по материалам 3-й ревизии) // Ежегодник по аграрной истории Восточной Европы. 1960. Киев, 1962. C. $236-247$.

${ }^{12}$ Вагина П. А. Формирование рабочих кадров на заводах Южного Урала в 50-60-х годах XVIII в. // Исторические записки. М., 1954. Т. 47. С. 308-326. 
Г. Н. Ульянова, И. А. Троицкая. Ревизские сказки как источник изучения исторической демографии...

вавшие преимущественно труд купленных крепостных крестьян. Таких заводов было 13 из 28 (в частности Белорецкий, Богоявленский, Усть-Катавский, Златоустовский, Юрезанский и др.), и они принадлежали Твердышеву и Мясникову. Подобная ситуация была на Кыштымских и Каслинском заводах Демидовых. Вагина установила, что только с 1744 по 1762 г. владельцы купили 6849 крепостных крестьян ${ }^{13}$.

Тогда же, в 1950-е гг., материалы ревизий в Сибири подвергла сбору и анализу М. М. Громыко, впоследствии видный историк и этнограф. Ее первые работы были посвящены истории русского крестьянства Сибири периода феодализма. Она, в частности, использовала материалы III и IV ревизий из Государственного архива Новосибирской области для получения данных о численности и миграциях приписных крестьян на Колыванско-Воскресенских заводах и рудниках, а затем крестьян церковных вотчин ${ }^{14}$. Позже, в монографии «Западная Сибирь в XVIII веке» (1965), Громыко подсчитала естественный прирост и миграционный поток на данных ревизий и подворных переписей из РГАДА и местных архивов $^{15}$.

В 1950-е гг. в Институте истории АН СССР вопросам исторической демографии, демографической дифференциации регионов отдал дань видный ученый Виктор Корнельевич Яцунский (1893-1966), опубликовавший в 1957 г. программную статью «Изменения в размещении населения Европейской России в 1724-1916 гг.» ${ }^{16}$. В этой статье была представлена динамика народонаселения с использованием данных ревизий (включая архивные), а для пореформенного периода - переписей населения 1897 и 1916 гг. Работа Яцунского положила начало изучению миграций в отечественной историографии.

Из студентов Яцунского, учившихся у него в Историко-архивном институте в 1950-е гг., сформировалась его научная школа, видными представителями которой стали Я. Е. Водарский (1928-2007), В. М. Кабузан (1932-2008), Б. Г. Литвак (1919-2002), Э. Г. Истомина (род. 1937), и в известной степени О. М. Медушевская (1922-2007).

Владимиру Максимовичу Кабузану Яцунский предложил заняться рассмотрением ревизских сказок как источника по истории народонаселения Российской империи. В 1959 г. Кабузан после окончания аспирантуры в МГИАИ защитил в Институте истории кандидатскую диссертацию, после чего с 1960 г. был взят в штат института, где проработал почти полвека (до кончины в 2008 г.).

В 1959 г. результаты своих штудий Кабузан представил в двух работах: фундаментальной статье «Материалы ревизий как источник по истории населения России XVIII - первой половины XIX в.», опубликованной в журнале «История

${ }^{13}$ См.: Вагина. Указ. соч. С. 313.

${ }^{14}$ См.: Громыко М. М. Некоторые особенности приписной деревни Западной Сибири второй половины XVIII в. // Ежегодник по аграрной истории Восточной Европы. 1960. Киев, 1962. С. 296-306; Она же. Крестьяне церковных вотчин Западной Сибири в 40-60-х годах XVIII века // Ежегодник по аграрной истории Восточной Европы. 1961 г. Рига, 1963. С. 262270.

${ }^{15}$ См.: Громыко М. М. Западная Сибирь в XVIII веке. Новосибирск, 1965.

${ }_{16}$ Яиунский B. K. Изменения в размещении населения Европейской России в 1724 1916 гг. // История СССР. 1957. № 1. С. 192-224. 
СССР», и в публикации (в соавторстве с Н. М. Шепуковой) под названием «Табель первой ревизии народонаселения России (1718-1727 гг.)»

Примечательно, что в публикации табели I ревизии констатируется, что «Материалы ревизий (переписей населения России XVIII - первой половины XIX в.) представляют забытый и малоизученный участок советской исторической науки, в то время как они являются единственным наиболее полным и систематизированным источником для изучения истории народонаселения нашей страны» ${ }^{18}$. Следует особо сказать, что столь ценный источник, как «Генеральная, учиненная ис переписных книг, о числе мужеска полу душ табель» (1738), был обнаружен Кабузаном и Шепуковой в РГАДА в фонде Сената (ф. 248). Этот источник, как установили Кабузан и Шепукова, «не был в достаточной мере использован ни дореволюционными, ни советскими историками». Лишь общие цифры брал С. М. Соловьев, ошибочно полагавший, что они являются данными переписи 1738 г. В основу табели были положены ведомости губернских канцелярий, составленные по переписным книгам генералитетской (первой) ревизии. Эта табель давала и уточненную (наибольшую, по сравнению с другими известными источниками) цифру народонаселения - 5710715 душ мужского пола (включая ямщиков и ряд других неокладных сословий).

В 1963 г. вышла монография Кабузана «Народонаселение России в XVIII первой половине XIX в. (по материалам ревизий)», и в 1971 г. монография «Изменения в размещении населения России в XVIII первой половине XIX в. (по материалам ревизий)» ${ }^{19}$. В обеих книгах Кабузан использовал ревизские сказки (точнее агрегированные показатели по количеству податного населения) для изучения народонаселения и миграций.

Сопоставление материалов ревизского, церковного и административнополицейского учета населения, по мнению Кабузана, дало основание судить о ревизиях как «самом полном и точном из всех источников по учету численности и состава населения России» ${ }^{20}$. Монография Кабузана 1963 г. явилась источниковедческим исследованием, в котором была представлена историография предшествующего обращения к ревизским сказкам как источнику, история разных видов учета населения в России (в том числе метрических книг, клировых табелей, окладных книг и др.) и их содержательная ценность.

${ }^{17}$ Кабузан В. М. Материалы ревизий как источник по истории населения России XVIII первой половины ХІХ в. (1718-1858 гг.) // История СССР. 1959. № 5. С. 128-140; Кабузан В. М., Шепукова Н. М. Табель первой ревизии народонаселения России (1718-1727 гг.) // Исторический архив. 1959. № 3. С. 126-130.

${ }^{18}$ Кабузан, Шепукова. Табель первой ревизии. С. 126.

${ }^{19}$ Кабузан В. М. Народонаселение России в XVIII - первой половине XIX в. (по материалам ревизий). М., 1963; Он же. Изменения в размещении населения России в XVIII - первой половине ХІХ в. (по материалам ревизий). М., 1971. Считаем правомерным включить книгу 1971 г. издания в наш обзор, поскольку, как правило, интервал между завершением книги и публикацией книги в издательстве «Наука» в период 1960-х - 1980-х гг. в среднем составлял 4-5 лет. В монографии 1971 г. были подведены итоги исследований, проведенных Кабузаном в 1960-е гг.

${ }^{20}$ Кабузан. Народонаселение России. С. 5. 
Г. Н. Ульянова, И. А. Троицкая. Ревизские сказки как источник изучения исторической демографии...

Важным результатом работы Кабузана, просмотревшего сотни документов в РГАДА, РГИА, РГВИА и ГАРФ (здесь мы даем современные названия архивов), стала оценка полноты и точности ревизского, церковного и административнополицейского видов учета населения. С невероятной тщательностью Кабузан проверил по источнику итоговые данные по народонаселению, ранее представленные в работах А. К. Шторха, И. И. Голикова, И. Ф. Германа, К. Ф. Германа, К. И. Арсеньева, П. И. Кеппена, Н. Экка, В. И. Семевского, С. М. Соловьева, В. Э. Дэна и др., и пришел к выводу, что в работах XX в. наблюдалось чаще всего некритическое использование цифр, взятых из работ XIX в., а к первоисточникам историки практически не обращались.

Оценивая монографию Кабузана, изданную в 1963 г. и весьма скоро признанную классической, следует отметить как большие достоинства ее стройную структуру и четкий стиль изложения. Но удивительно то, что автор завершил ее, будучи всего 30 лет от роду. Такие моменты озарения при полнейшем погружении в тему, приводившие к выдающимся результатам, можно найти в биографиях ряда историков.

В последующие годы Кабузан продолжил работу с ревизскими сказками для изучения больших демографических процессов на региональном уровне ${ }^{21}$.

В 1960-е гг. историки начинают всё активнее использовать ревизские сказки в своих штудиях. Они изучают не только численность, размещение и миграции крестьянского населения (занимавшегося сельским хозяйством и приписанного к заводам), но и социальную структуру городов. Одновременно становится разнообразным региональный охват исследований. Результаты чаще всего были представлены в «Ежегоднике по аграрной истории Восточной Европы» и в «Исторических записках» - оба этих периодических издания готовились Институтом истории АН СССР.

Так, Шепукова использовала материалы всех десяти ревизий при написании кандидатской диссертации «Изменение удельного веса помещичьих крестьян в составе населения Европейской России в XVIII - 1-й половине XIX вв. (1718-1858 гг.)», защищенной в 1960 г. ${ }^{22}$ Основные результаты были представ-

${ }^{21}$ В работе «Изменения в размещении населения России в XVIII - первой половине XIX в. (по материалам ревизий)» В. М. Кабузан, обильно используя сведения ревизских сказок всех десяти ревизий, рассмотрел динамику численности населения и миграций в контексте географической трансформации территории страны, в первую очередь связанную с приращением новых земель (Прибалтики, губерний Левобережной и Правобережной Украины, Белоруссии, Таврической губ., Бессарабии). Он отметил влияние войн и эпидемий на темпы прироста населения. Три четверти объема книги (140 из 190 страниц) отдано табличным приложениям, составленным по ревизским материалам из РГАДА (I-V ревизии) и РГИА (VI-X ревизии). В книге «Народы России в XVIII веке. Численность и этнический состав» (М., 1990) В. М. Кабузан использовал данные ревизского учета для изучения динамики национального состава населения, а в монографии «Распространение православия и других конфессий в России в XVIII - начале XX в. (1719-1917 гг.)» (М., 2008) - для анализа конфессионального состава населения Российской империи.

${ }^{22}$ Шепукова Н. М. Изменение удельного веса помещичьих крестьян в составе населения Европейской России в XVIII - 1-й половине XIX в. (1718-1858 гг.). Дис. ... канд. ист. наук. М., 1960. 
лены Шепуковой в статьях, опубликованных в журнале «Вопросы истории» и в «Ежегоднике аграрной истории Восточной Европы» ${ }^{23}$.

Если в 1950-е годы внимание ученых было сосредоточено на применении ревизских сказок как источника для изучения крестьянства, то 1960-е годы были отмечены успешным использованием материалов ревизий для исследования истории городов, торговли и промышленности.

М. Я. Волков (Институт истории СССР АН СССР) тщательно работал с материалами I и II ревизий из ф. 350 РГАДА (Ландратские книги и ревизские сказки). Результаты его штудий по анализу сказок и их применимости в качестве источника были представлены в статье «Материалы первой ревизии как источник по истории торговли и промышленности России первой половины XVIII в.» ${ }^{24}$.

Позже, в сборнике к 70-летию Л. Г. Бескровного, была опубликована статья М. Я. Волкова «Города Тверской провинции в первой четверти XVIII в.». В ней по материалам I ревизии были проанализированы данные о численности податного населения - купцов и мещан - его сословном и социальном составе, занятиях (земледелие, ремесло, торговля, «черная работа», нищенство) по шести уездным городам Тверской губернии - Твери, Торжку, Старице, Ржеву, Зубцову, Погорелому Городищу. Весьма интересны подсчеты по профилю ремесленных занятий по Торжку, где представители 261 семьи имели 24 специальности, наиболее распространенными из которых были сапожники (59 семей), кузнецы (41), кожевники (36), рукавичники (33) и плотники (12). В Твери же было 376 семей с 40 специальностями, среди которых насчитывалось наибольшее количество кузнецов (72), калачников, хлебников и квасников (40), маслеников (31) и замочников (31), что показывало существенное различие крупного города с меньшим по размеру Торжком ${ }^{25}$. Сопоставление статистики ревизий с писцовыми и переписными книгами XVII в. позволило проследить динамику социальноэкономических параметров. Позже результаты были обобщены М. Я. Волковым в монографии «Города Верхнего Поволжья и Северо-Запада России. Первая четверть XVIII в.» ${ }^{26}$.

${ }^{23}$ В частности: Шепукова Н. М. Изменение удельного веса частновладельческого крестьянства в составе населения Европейской России в XVIII - начале XIX в. // Вопросы истории. 1959. № 12. С. 123-136; Она же. Об изменении размеров душевладения помещиков Европейской России в первой четверти XVIII - первой половине XIX в. // Ежегодник по аграрной истории Восточной Европы. 1963 год. Вильнюс, 1964. С. 402-419; Она же. К вопросу о численности барщинных и оброчных помещичьих крестьян Европейской России во 2-й половине XVIII века // Ежегодник по аграрной истории Восточной Европы. 1964 год. Кишинев, 1966. C. 400-408.

${ }^{24}$ Волков М. Я. Материалы первой ревизии как источник по истории торговли и промышленности России первой половины XVIII в. // Проблемы источниковедения. Т. XI. М., 1963. C. 266-306; Он же. Города Тверской провинции в первой четверти XVIII в. // Историческая география России. XII - начало XX в.: Сб. ст. к 70-летию профессора Л. Г. Бескровного. М., 1975. C. $143-163$.

${ }^{25}$ См.: Волков. Города Тверской провинции. С. 157-158.

${ }^{26}$ Волков М. Я. Города Верхнего Поволжья и Северо-Запада России. Первая четверть XVIII в. M., 1994. 
Г. Н. Ульянова, И. А. Троицкая. Ревизские сказки как источник изучения исторической демографии...

Историей городов Среднего Поволжья занимался И. А. Булыгин. В статье «Об особенностях городов Среднего Поволжья во второй половине XVIII в.» ${ }^{27}$ он использовал для характеристики населения Пензенской губ. во второй половине XVIII в. материалы III-V ревизий из РГАДА (ф. 248 - Сенат) и Пензенского архива. Это позволило установить сословную и территориальную градацию населения по 13 городам (Пенза, Саранск, Верхний Ломов, Нижний Ломов, Инсар, Керенск, Наровчат, Краснослободск, Троицк, Мокшаны, Шешкеев, Чембар, Городищи). Подсчеты показали, что в городском населении существенную долю составляли лица с сословным статусом государственных крестьян. Это были «бывшие служилые люди по прибору, в деятельности которых главное место теперь заняло сельское хозяйство» ${ }^{28}$, и доля их по III ревизии составляла в Саранске $-57,2 \%$, в Пензе - 68,7\%, в Инсаре $-72,0 \%$, в Верхнем Ломове - 84,3\%, в прочих городах 94-99\%. А торгово-ремесленное население (купцы и мещане) представляли меньшинство. Работа с демографическими данными позволила Булыгину сделать вывод о земледельческом характере городов в изучаемый период, сохраняемом, несмотря на рост местного купечества и мещанства, которое занималось главным образом поставками хлеба в центральные районы России.

В историографическом обзоре нельзя обойти вниманием вопрос о том, как исследования 1950-1960-х гг. оценивались в последующей историографии. Наиболее полно, можно сказать исчерпывающе, период обращения к сказкам в 1950-1960-е гг. был представлен и проанализирован в монографии Н. А. Горской (1930-2004) «Историческая демография России эпохи феодализма. (Итоги и проблемы изучения)» 29 . Глава «Отечественная историография историкодемографических процессов XVIII в.» в значительной мере посвящена использованию материалов I-III ревизий ${ }^{30}$.

Анализируя изучение численности населения, его плотности, расселения и миграций отечественными историками, Горская отметила, что «советская историография до 50-х годов к материалам ревизий XVIII в. интереса почти не проявляла» (за исключением саратовской группы историков в 1920 -е гг.) ${ }^{31}$. В конце 1950-х гг. исследование истории народонаселения с привлечением данных ревизий возобновил В. К. Яцунский, позже В. М. Кабузан, Н. М. Шепукова, Е. И. Индова, М. М. Громыко. Трудам В. М. Кабузана Горская уделила серьезное внимание, отмечая, что заслугой исследователя стал ответ на вопрос о полноте, точности и достоверности ревизских сказок, а также вывод о том, что в сводных архивных материалах не нашли отражения многие вопросы, поставленные в сказках. Представляется весьма важным вывод Горской, что «вся историография $70-80$-х годов в вопросах определения общей численности и движения населения России XVIII в., охваченного ревизским учетом, опирается на источнико-

${ }^{27}$ Булыгин И. А. Об особенностях городов Среднего Поволжья во второй половине XVIII в. // Города феодальной России. М., 1967. С. 486-497.

${ }^{28}$ Там же. С. 491.

${ }^{29}$ Горская Н. А. Историческая демография России эпохи феодализма: Итоги и проблемы изучения. М., 1994.

${ }^{30}$ См.: Там же. С. $165-179$.

${ }^{31}$ Там же. С. 166. 
ведческие наблюдения и конкретные подсчеты, произведенные Кабузаном», а более поздние уточнения «относятся обычно к отдельным регионам» ${ }^{32}$.

Оценивая книгу В. М. Кабузана об изменениях в размещении населения России в XVIII - первой половине XIX в. (1971), Горская приводит в качестве весомого результата данные о приросте населения между ревизиями, хотя и считает объяснение темпов прироста Кабузаном не вполне удовлетворительным.

Кроме численности населения в целом и крестьянского населения, плодотворное применение материалов ревизий, по мнению Горской, отмечено при изучении города в XVIII - первой половине XIX в. (в трудах Ю. Р. Клокмана, П. Г. Рындзюнского и др. $\left.{ }^{33}\right)$, и особенно при изучении динамики социального состава населения России.

Горская отметила, что изменение социального состава было представлено в трудах ряда московских исследователей. Прежде всего В. М. Кабузаном и Н. М. Шепуковой по ревизиям были произведены подсчеты крепостного населения: оно возрастало абсолютно, например с 3176 тыс. по I ревизии до 4401,5 тыс. по IV ревизии, но при этом уменьшалась его доля в составе всего населения (около $52 \%$ во II и III ревизии, $48,77 \%$ в IV ревизию) ${ }^{34}$.

Горская также упоминает серьезные результаты исследований отдельных категорий крестьянства, достигнутые Е. И. Индовой (дворцовые крестьяне), М. М. Громыко (государственные крестьяне), И. А. Булыгиным и А. М. Комиссаренко (монастырские крестьяне).

Высокий уровень историографических штудий Горской определялся тем, что она сама была крупным исследователем, хорошо знавшим архивные источники, их достоинства и недостатки. Она понимала сложности лабораторной работы историка, обусловливаемые недоступностью или малой доступностью источников, трудоемкостью их обработки. Всё это делает чтение историографических работ Горской отправной точкой для новых поколений исследователей, обращающихся к ревизским сказкам и другим массовым источникам.

В истории российской исторической науки 1950-1960-е гг. можно рассматривать как переломные. Они характеризовались отходом от прежней, господствовавшей в предыдущее двадцатилетие жесткой идеологической матрицы вследствие изменений в политической жизни страны. Концентрация исключительно на истории классовой борьбы понемногу исчезает. При рассмотрении социально-экономической истории страны в XVIII и XIX вв. историки вновь возвратились к академической постановке вопросов. Расширялось поле исследования, что сопровождалось обращением к архивным источникам, одним из которых являются ревизские сказки.

\footnotetext{
${ }^{32}$ Горская. Указ. соч. С. 168.

${ }^{33}$ Клокман Ю. Р. Очерки социально-экономической истории городов Северо-Запада России в середине XVIII в. М., 1960; Клокман Ю. Р. Социально-экономическая история русского города. Вторая половина XVIII в. М., 1967; Рындзюнский П. Г. Городское гражданство дореформенной России. М., 1958.

${ }^{34}$ Горская. Указ. соч. С. 172.
} 
Г. Н. Ульянова, И. А. Троицкая. Ревизские сказки как источник изучения исторической демографии...

Однако в этот период господствовал подход, при котором исследователи еще не ставили перед собой задачу восстановления полной картины демографического развития России в прошлом. Те или иные показатели были использованы в качестве демографической характеристики различных исторических событий и процессов, например социального расслоения крестьянства, процесса колонизации, генезиса капитализма, развития системы землепользования и сельского хозяйства в целом. В качестве метода применялся сбор, подсчет и статистический анализ демографической информации.

Введение в научный оборот ревизских сказок не только крестьянства, но и купечества, расширение регионального охвата исследований, изучение демографического поведения, выделение в качестве единиц учета семей и домохозяйств, установление их типологии - все эти вопросы стали содержанием дальнейшего периода развития исторической науки.

Ключевые слова: историческая демография, историография, история городов, региональная история, ревизские сказки, история России XVIII и XIX веков, имперская Россия.

\section{Russian Poll-tax Registers (soul Revisions) as a Source for the Historical Demography Studies IN THE 1950s AND 1960s}

\section{G. Ulianova, I. TROITSKayA}

The essay describes the 1950s and the 1960s as an important period in the study of poll-tax registers (soul revisions). This period began with the publication of E. P. Podyapolskaya's article, titled «Poll-tax registers (soul revisions) as a historical source», in the compendium to the 70th anniversary of academician B. D. Grekov in 1952. Interest in poll-tax registers as a source was resumed after a 35-year period of oblivion, when the change in the political life of the USSR has seen a departure from the former rigid ideological matrix. When considering the socio-economic history of the Russia in the eighteenth and nineteenth centuries, historians returned to the academic questions. The number of papers that have used poll-tax registers was not large, but they were distinguished by the depth and thoroughness of analysis. A considerable amount of documents, especially from the Russian state archive of ancient acts and the Russian state historical archive, was introduced into research space. The article analyses the works that have studied the different categories of peasants, including the population of the mining districts. The period 1960s has also become an important stage in the study of social structure of cities and their craft specialization based on the poll-tax registers analysis. In the essay special attention is paid to the role of the three researchers in the history of historical demography, such as V. K. Yatsunsky, who created the scientific school in 
this field, V. M. Kabuzan, who introduced poll-tax registers into investigation of various aspects of the demographic history of the Russian Empire, and N. A. Gorskaya, who analyzed in detail the vast historiography of the research field.

Keywords: historical demography, historiography, urban and regional history, russian poll-tax registers (so-called revisions), 18th and 19th centuries russian history, imperial Russia.

\section{Список литературы}

1. Булыгин И. А. Об особенностях городов Среднего Поволжья во второй половине XVIII в. // Города феодальной России. М., 1967. С. 486-497.

2. Вагина П. А. Формирование рабочих кадров на заводах Южного Урала в 50-60-х годах XVIII в. // Исторические записки. М., 1954. Т. 47. С. 308-326.

3. Волков М. Я. Города Верхнего Поволжья и Северо-Запада России. Первая четверть XVIII в. М., 1994.

4. Волков М. Я. Города Тверской провинции в первой четверти XVIII в. // Историческая география России, XII - начало XX в.: Сб. ст. к 70-летию профессора Л. Г. Бескровного. М., 1975. С. 143-163.

5. Волков М. Я. Материалы первой ревизии как источник по истории торговли и промышленности России первой половины XVIII в. // Проблемы источниковедения. М., 1963. T. XI. C. $266-306$.

6. Волков С. И. Подмосковные дворцовые крестьяне в середине XVIII в. // Исторические записки. М., 1955. Т. 53. С. 189-210.

7. Горская Н. А. Историческая демография России эпохи феодализма: Итоги и проблемы изучения. М., 1994.

8. Громыко М. М. Западная Сибирь в XVIII веке. Новосибирск, 1965.

9. Громыко М. М. Крестьяне церковных вотчин Западной Сибири в 40-60-х годах XVIII века // Ежегодник по аграрной истории Восточной Европы. 1961 г. Рига, 1963. C. $262-270$

10. Громыко М. М. Некоторые особенности приписной деревни Западной Сибири второй половины XVIII в. // Ежегодник по аграрной истории Восточной Европы. 1960 г. Киев, 1962. С. 296-306.

11. Индова Е. И. Дворцовое хозяйство в России. Первая половина XVIII века. М., 1964.

12. Кабузан В. М. Изменения в размещении населения России в XVIII - первой половине ХІХ в. (по материалам ревизий). М., 1971.

13. Кабузан В. М. Материалы ревизий как источник по истории населения России XVIII первой половины XIX в. (1718-1858 гг.) // История СССР. 1959. № 5. С. 128-140.

14. Кабузан В. М. Народонаселение России в XVIII - первой половине XIX в. (по материалам ревизий). М., 1963.

15. Кабузан В. М. Народы России в XVIII веке: Численность и этнический состав. М., 1990.

16. Кабузан В. М., Шепукова Н. М. Табель первой ревизии народонаселения России (17181727 гг.) // Исторический архив. 1959. № 3. С. 126-130.

17. Клокман Ю. Р. Очерки социально-экономической истории городов Северо-Запада России в середине XVIII в. М., 1960.

18. Клокман Ю. Р. Социально-экономическая история русского города. Вторая половина XVIII в. M., 1967.

19. Подъяпольская Е. И. Ревизские сказки как исторический источник // Академику Б. Д. Грекову ко дню семидесятилетия. М., 1952. С. 311-321. 
Г. Н. Ульянова, И. А. Троицкая. Ревизские сказки как источник изучения исторической демографии...

20. Рындзюнский П. Г. Городское гражданство дореформенной России. М., 1958.

21. Шепукова Н. М. Изменение удельного веса помещичьих крестьян в составе населения Европейской России в XVIII - 1-й половине XIX в. (1718-1858 гг.). Дис. ... канд. ист. наук. М., 1960.

22. Шепукова Н. М. Изменение удельного веса частновладельческого крестьянства в составе населения Европейской России в XVIII - начале XIX в. // Вопросы истории. 1959. № 12. С. 123-136.

23. Шепукова H. М. К вопросу о численности барщинных и оброчных помещичьих крестьян Европейской России во 2-й половине XVIII века // Ежегодник по аграрной истории Восточной Европы. 1964 год. Кишинев, 1966. С. 400-408.

24. Шепукова Н. М. Об изменении размеров душевладения помещиков Европейской России в первой четверти XVIII - первой половине XIX в. // Ежегодник по аграрной истории Восточной Европы. 1963 год. Вильнюс, 1964. С. 402-419.

25. Яиунский B. K. Изменения в размещении населения Европейской России в $1724-$ 1916 гг. // История СССР. 1957. № 1. С. 192-224. 